\title{
系列二分決定グラフを用いたタンパク質配列モチーフ の多重表現
}

\author{
大和 康平 $^{\mathrm{a}}$, 加藤 博明 ${ }^{\mathrm{b}^{*}}$, 桂樹 哲雄 ${ }^{\mathrm{a}}$, 高橋 由雅 ${ }^{\mathrm{a}}$ \\ a 豊橋技術科学大学 情報・知能工学系 干 441-8580 愛知県豊橋市天伯町雲雀ヶ丘 1-1 \\ $\mathrm{b}$ 広島商船高等専門学校 流通情報工学科 $=725-0231$ 広島県豊田郡大崎上島町東野 4272-1 \\ *e-mail:kato@hiroshima-cmt.ac.jp
}

(Received: August 21, 2019; Accepted for publication: March 25, 2020; Online publication: June 15, 2020)

本稿では, 系列二分決定グラフ (SeqBDD)を用いたタンパク質配列モチーフの多重表現とそのモチーフ 検索への応用について述べる. SeqBDDは, 複数の文字列のような配列集合の圧縮表現である. 本研究で は, SeqBDDのための二つのアルゴリズムを開発した.一つ目は, 対応するモチーフのアミノ酸配列を表 現するSeqBDDを構築するためのもので, 二つ目は状態遷移を追加することにより, SeqBDDのための決 定性有限オートマトン (DFA) に相当するオートマトンを構築するためのものである. 性能評価のために, マトリクスメタロプロテアーゼ(MMP) ファミリーにおいて保存されている三つのドメインを, UniProtKB/ Swiss-Prot (Rel. 2017_09)から得られた555,594の全てのアミノ酸配列に対して検索した. PROSITEパター ンを使用した同様の検索結果と比較して, 本手法は, 適合率, 再現率, およびF值において良好な結果を 示した.

キーワード: Sequence binary decision diagram, Aho-Corasick algorithm, Multiple representation, Sequence motif, Motif search

\section{1 はじめに}

タンパク質は 20 種類のアミノ酸が直鎖状にペプチド結 合して構成され，折りたたまれることで固有の立体構造 をとり, 機能を発現する. タンパク質のアミノ酸配列中 には局所的に保存されている領域が存在し，その領域は 配列モチーフと呼ばれている [1]. 配列モチーフは, 機 能と関連することも多く,アミノ酸配列中に配列モチー フが存在するか確認することで, 機能未知タンパク質の 機能推定に活用されている [2-4]. 配列モチーフは, 一 般に相同性の高いアミノ酸配列や機能を共通して持つタ ンパク質のアミノ酸配列をマルチプルアラインメントに より整列することで得られる [5].この保存されている 領域のアミノ酸配列群をもとに, 配列モチーフを表現す るモチーフモデルが生成される.

シンプルなモチーフモデルの一つとして, 正規表現に
基づくPROSITE pattern [6]が広く用いられている。 また, 出現確率を考慮した定量的なモチーフモデルとして, 重 み行列によるPROSITE profile [6]や，隠れマルコフモデ ル(HMM)によるPfam [7]などが提案されている，十分に 確立されたモチーフに対して, これらのモチーフモデル は非常に有用である. しかしながら，機能未知のタンパ ク質も多く存在し, 新規モチーフ候補部位の発見に向け て, 様々な試みが行われている. そうした中で, 従来と は異なる構造特徴表現もまた必要とされている.

特定の機能を有するタンパク質のアミノ酸配列は, 一 般に相同性が高く, ファミリーを構成する. ファミリー に固有な配列モチーフは, 複数種類のモチーフの組み合 わせとして存在することも報告されている [8]. 例えば, マトリクスメタロプロテアーゼ (MMP) ファミリーに属 するタンパク質には, 活性ドメインを示すZinc protease モチーフと, 活性を阻害するCysteine switchモチーフが 


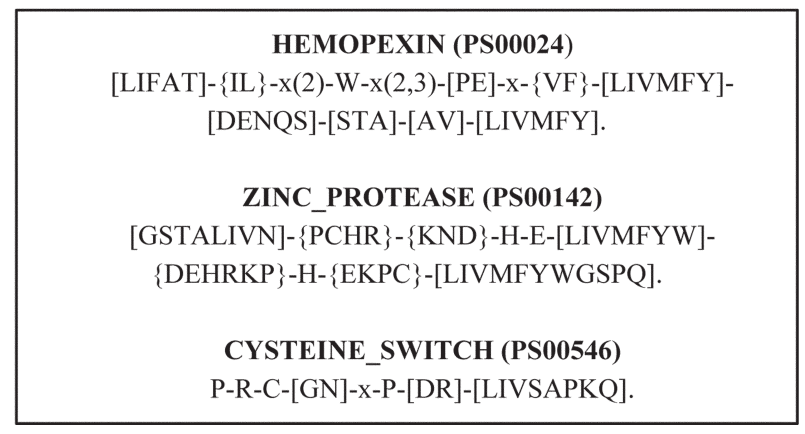

Figure 1. PROSITE patterns for the MMP sequence motif

共に存在することが知られている [9]. こうした, タン パク質中の配列モチーフの組み合わせに注目した解析も 試みられている $[10,11]$. 共起関係にある配列モチーフ を表現する場合, PROSITE patternなど既存の方法では, 各々のモチーフを一つずつ全て記述する必要がある。

本研究では, 配列モチーフ(候補)抽出時のアミノ酸 配列群をそのまま表現するモチーフモデルとして, 系列 二分決定グラフ (sequence binary decision diagram, 以下 SeqBDD) [12]の概念を活用し, 複数種の配列モチーフ集 合を一つの SeqBDD として圧縮して記述するための新た な方法を提案する。また，配列モチーフ集合のSeqBDD 表現を基礎とした配列モチーフ検索のためのアルゴリズ ムを開発するとともに，PROSITE patternに登録されてい るMMPタンパク質の共起モチーフ群を例に，その検索 精度に関する計算機実験を通じて本提案手法の優位性を 示す.

\section{2 方法}

\section{1 配列モチーフの例}

Figure 1に, MMPファミリーに属するタンパク質が持 つZinc protease モチーフ, Cysteine switchモチーフ，およ びHemopexin モチーフの三つの配列モチーフをPROSITE patternにより表現した例を示す. 文字列パターンは1残 基毎にハイフン (-) で区切られており, P-R-Cのように, それぞれ1文字で表現されるアミノ酸残基は特定の位置 に存在することを示している. [GN] のように角括弧で まとめられているものは, 出現する残基のうちいずれか 一つを示す. $\mathrm{x}$ は, 任意のアミノ酸残基に対応する. 一 方，\{IL\} のような波括弧は，指定されているもの以外の

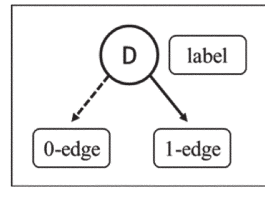

Figure 2. The elements of SeqBDD

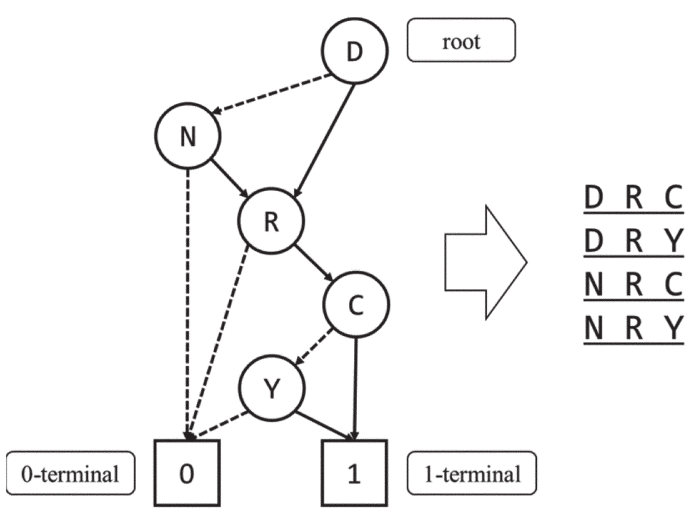

Figure 3. An example of SeqBDD representing a set of amino acid sequences

アミノ酸残基を示す. 丸括弧で示されるのは, その直前 のアミノ酸残基の繰り返しであり, $\mathrm{x}(2,3)$ のように二つ の数字の組は繰り返し回数の幅を示す.

\section{2 系列二分決定グラフ}

SeqBDDは, 系列集合を圧縮して表現する有向非巡 回グラフである. SeqBDDの節点は, 系列の要素を表 現するラベル, 要素が存在することを示す1-枝, およ び要素が存在しないことを示す 0-枝で構成される [12]. Figure 2 に示す節点の例では, ラベルはアスパラギン 酸を1文字表記 (D) により表現している.またSeqBDD は, 系列が存在することを示す1-終端節点と, 系列が 存在しないことを示す 0 - 終端節点の二つの終端を持つ. SeqBDDは, 内包する系列集合に応じて一つの根節点を 持つ. SeqBDDに含まれる系列は, 根節点から 1-終端節 点への経路と対応し, その各経路は, 1-枝を通った節点 のラベルが示す要素を並べたものにそれぞれ対応する.

Figure 3 に, 配列長 3 の 4 種類の異なるアミノ酸配列を 用いた, SeqBDDによる系列集合の圧縮表現の例を模式 的に示す.このSeqBDDは, アミノ酸配列集合 $\{$ DRC, DRY, NRC, NRY \} を表現している. 


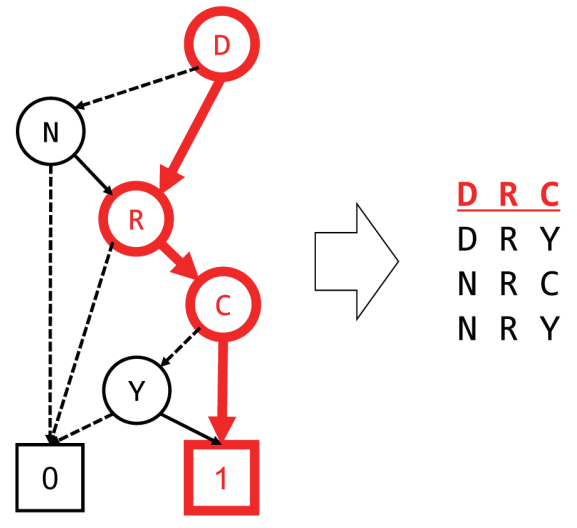

Figure 4. A path in SeqBDD corresponding to a sequence DRC

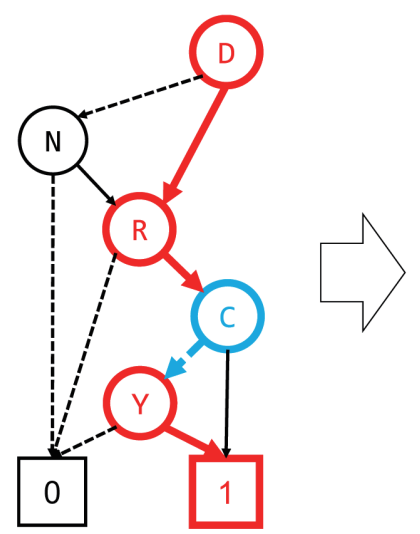

D R C

D R Y

N R C

N R Y

Figure 5. A path in SeqBDD corresponding to a sequence DRY

Figure 4で強調して示す経路は，1-枝を通る節点のラ ベル D， RおよびCを並べたアミノ酸配列 DRC と対応し ている. 一方, Figure 5で強調して示す経路は, Cのラ ベルを持つ節点は 0 -枝を通るため, 経路上の節点のラベ ルのうち，Cを除いて並べたアミノ酸配列 DRY と対応す る.

SeqBDDは, 系列を表現する複数のSeqBDDの節点を 共有することで得られる. 例として, アミノ酸配列 RC, RYからそれぞれSeqBDDを生成し, 各SeqBDDを合成 することで得た，アミノ酸配列集合 $\{\mathrm{RC}, \mathrm{RY}\}$ を表現す る新たなSeqBDDを Figure 6に示す。一つの系列を表現 するSeqBDDは, 根節点から 1-終端節点に向かって, 系 列の要素を表現するラベルを持つ節点が，1-枝側に並ん だ構造をしている. Figure 6のRCを表現するSeqBDDで は, 根節点から順に，ラベル R, Cを持つ節点が並んで

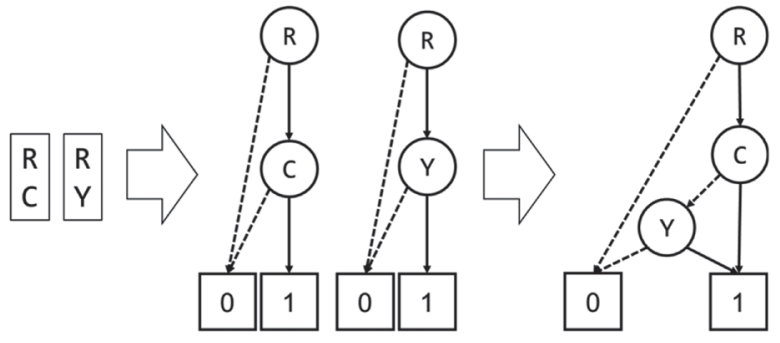

Figure 6. An example of constructing SeqBDD from a set of amino acid sequences

いる，二つのSeqBDDを合成するには，根節点から再帰 的に節点を参照する. 以下にその手順を示す：二つの SeqBDDは, それぞれの根節点はラベルRを共有するよ

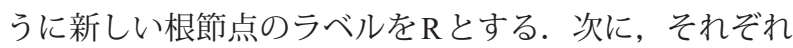
のSeqBDDの1-枝に接続している節点のラベルを参照す ると，ラベルはそれぞれC，Yである．このとき，予め 定められたラベルの優先順位に従い，節点を0-枝に接続 する．本研究では，ラベルの優先順位を辞書順としてい るため, ラベルCを持つ節点の0-枝に, ラベルYを持つ 節点を接続する. 最後に, 要素が存在することを示す1終端節点に，それぞれの節点の1-枝を接続し，残つた0枝に0-終端節点を接続することで, 目的のSeqBDDを得 る.

SeqBDDの特徵を以下に述べる. SeqBDDの形状は, 内包する系列と節点のラベルの順序により, 一意に定ま ることが知られている [13]. SeqBDDは, 根節点の0-枝 を順に辿ると, グラフが表現する系列集合の先頭のラベ ルを持つ節点が並ぶ構造である.

Figure 3 では，アミノ酸配列集合の先頭の残基 Dおよ びNを持つ節点が並んでいる．これらの先頭の要素の 1-枝の先の節点の 0 -枝を辿ると，2番目の要素を持つ節 点が同様に並ぶ構造をしている. Figure 3 では, 各アミ ノ酸配列が共有する残基 $\mathrm{R}$ を持つ節点のみが存在してい る. このように, 内包する系列の先頭の要素から順番に 共有する構造となっている. また, 1-終端節点に接続さ れる節点は, 最大でも要素の種類数, アミノ酸残基の場 合は高々 20 個であり, 未尾の要素についても共有され る. SeqBDDで文字列集合を表現する場合には，それぞ れ接頭辞および接尾辞が共有されると考えられる. さら に, Table 1に示すような, SeqBDDで表現する系列集合 に対する集合演算のアルゴリズムが知られている [14]. 
Table 1 An example of set operations for SeqBDD

\begin{tabular}{ll}
\hline Operation & Result \\
\hline$\varnothing$ & Empty set (0-terminal node) \\
$\{\lambda\}$ & A set of empty series (1-terminal node) \\
$\mathbf{P} \cap \mathbf{Q}$ & Intersection of P and Q \\
$\mathbf{P} \cup \mathbf{Q}$ & Union of P and Q \\
$\mathbf{P} \backslash \mathbf{Q}$ & Difference of P and Q \\
$\mathbf{P . o n s e t}(\boldsymbol{x})$ & A set of series with $\mathrm{x}$ at the beginning of $\mathrm{P}$ \\
$\mathbf{P . o f f s e t}(\boldsymbol{x})$ & A set of series without $\mathrm{x}$ at the beginning of $\mathrm{P}$ \\
$\mathbf{P . p u s h}(\boldsymbol{x})$ & A set with $\mathrm{x}$ appended to the beginning of $\mathrm{P}$ \\
$\mathbf{P . t o p}$ & Root node label of $\mathrm{P}$ \\
$\mathbf{P . c o u n t}$ & Number of elements of $\mathrm{P}$ \\
\hline
\end{tabular}

\section{3 系列二分決定グラフを用いた配列モ チーフの多重表現}

本研究では, 配列モチーフの記述表現として, SeqBDDを用いる.SeqBDDを用いることで, 配列モ チーフに対応するアミノ酸配列を圧縮して, 網羅的に含 むことができる. Figure 3の例では, 合計 12 残基からな るアミノ酸配列を，5節点と二つの終端で表現している. SeqBDDでは, 条件に一致するアミノ酸配列を明示的に 表現するため, 正規表現と比較して精度の向上が期待で きる. また, 配列モチーフの組み合わせが存在すると き, Table 1 に示す集合演算を用いることで, 複数のモデ ルを一つに集約することができる，すなわち，SeqBDD を用いたモチーフモデルでは, 一つのモデルで複数の配 列モチーフ群を記述できる.

なお，任意のアミノ酸xが位置する部分は, SeqBDD では 20 種類のアミノ酸と 0 -枝の組み合わせで表現でき る.ただし，例えば $\mathrm{x}(10,20)$ のように配列的なギャップ 領域と考えられるものは, むしろ, その前後の保存領域 の二つのパターンが共起するモチーフとして表現する. これにより, シャッフリングのように進化の過程で配列 的には大きな変異があるものの, 空間的な関係を保って いるような機能部位の構造特徴も扱うことができると考 える.

\section{4 配列モチーフ検索}

配列モチーフ検索は文字列処理により行われるため, 例えば正規表現を用いたモチーフ表現モデルでは，文
字列パターンから決定性有限オートマトン (deterministic finite automaton, DFA) を構築することにより検索を行う [15]．正規表現は，一般に一致する複数の文字列を表現 するため，DFAを用いることで単純な網羅的文字列マッ チング (以下, 単純文字列マッチング) よりも効率的に 検索可能である. SeqBDDを用いたモチーフモデルの場 合, 単純文字列マッチングでは, 検索対象のアミノ酸配 列を 1 残基ずつずらしてグラフ中の経路と比較すること で検索を行う。しかしこの方法では, アミノ酸配列長を $n$, 根節点と 1 -終端節点の間の最長経路長を $h$ とすると き，最悪時間計算量は $O(n h)$ となる.

SeqBDD と同様に文字列集合を表現するデータ構造に, トライ [16]と呼ばれる木構造がある. このトライを基に して, 文字列検索のためのDFAを構築するアルゴリズム (Aho-Corasick法 [17]) が知られている. Figure 7に, AhoCorasick法により得られた，アミノ酸配列集合 $\{\mathrm{DR}$, DRY, R, RY, YDR, YDRY \} により配列モチーフ検索を行 うDFAの例を示す。ここで, 状態を丸, 特に受理状態を 二重丸で表し，一致時の遷移をラベル付き有向辺，不一 致時の状態遷移をラベルなし有向辺でそれぞれ示す．本 研究では, このAho-Corasick法による複数文字列検索と 同様に, SeqBDD 上に探索失敗時の状態遷移を追加する ことで, SeqBDDをDFAとして配列モチーフ検索に応用 することを試みた. 


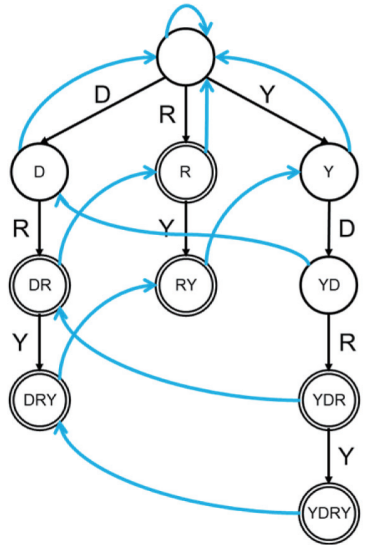

Figure 7. An example of DFA for a set of sequence \{ DR, DRY, R, RY, YDR, YDRY \} obtained by Aho-Corasick algorithm

\begin{tabular}{|ll|}
\hline failure $(\lambda)=\lambda$ & failure $(\mathrm{RY})=\mathrm{Y}$ \\
failure $(D)=\lambda$ & failure $(\mathrm{Y})=\lambda$ \\
failure $(D R)=\mathrm{R}$ & failure $(\mathrm{YD})=\mathrm{D}$ \\
failure $(D R Y)=\mathrm{RY}$ & failure $(\mathrm{YDR})=\mathrm{DR}$ \\
failure $(\mathrm{R})=\lambda$ & failure $(\mathrm{YDRY})=\mathrm{DRY}$ \\
\hline
\end{tabular}

Figure 8. An example of a failure function for Figure 7

\section{5 系列二分決定グラフを用いた検索ア ルゴリズム}

Aho-Corasick法では, 文字の不一致時の状態遷移を failure関数で表現する. Figure 7の例では, Figure 8 に示 す failure関数を用いる。このfailure関数をSeqBDDにお いて再現することで，トライの場合と同様に効率的に文 字列検索が可能になる. しかし, Figure 9に示すように, SeqBDDはトライと異なり, 一つの節点が複数の文字列 の中で使われる. 特に, Figure 9のアミノ酸配列集合 $\{\mathrm{D}$, YD \} の状態を表現するRのラベルを持つ節点は, その 節点の1-枝が接続している，Yのラベルを持つ節点の 0 枝が1-終端節点に接続されているため, DFAにおける受 理状態に相当する. このような各節点の文字列, すなわ ち状態を区別することで, SeqBDDにおいても failure 関 数による状態遷移を実現できる，本研究では，failure関 数構築時にはスタック, 検索時にはキューを用いて複数 の文字列を区別する。

まず，任意のSeqBDDにおける failure関数を求めるア ルゴリズムを示す. Ahoらは, 現在の節点を入力, 遷移 先の節点を出力とする failure関数を用いたが, 提案手法

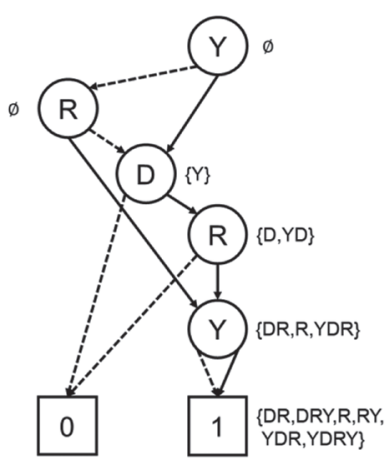

(a) SeqBDD

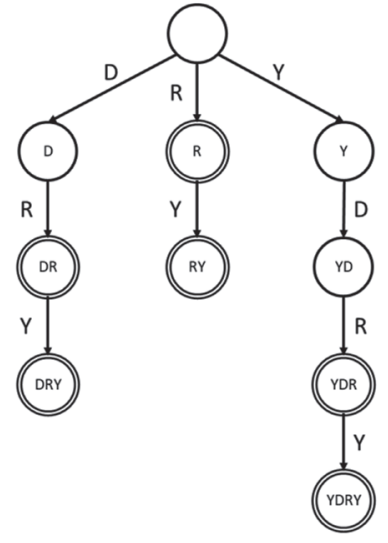

(b) Trie
Figure 9. SeqBDD and trie for an identical set of sequence

ではこれを拡張する. SeqBDDを用いて文字列を検索す るために，現在の状態を節点とスタックにより表現す る. そのため, 本研究における failure関数は, 現在の節 点とその文字列を示すスタックを入力, 遷移先の節点 と文字列の先頭から除去する文字数を出力とする. こ の failure関数で表現する状態の遷移先は，その状態と対 応する文字列の先頭の 1 文字を除いた最長接尾辞と対応 する状態であるため, 遷移先の状態は 0 -枝を優先して 探索することで求めることができる. SeqBDDにおいて failure 関数を求めるアルゴリズムを Algorithm1 に示す. ここでは, 節点nodeのラベルをnode.label, 0-枝をnode. branch0，および1-枝をnode.branch 1 と表すものとする. また， 0 -終端節点を 0,1 -終端節点を 1 でそれぞれ示す. Algorithm 1 におけるtrance 関数では, 各節点における遷 移先をnext_state関数により求め, 各節点の0-枝, 1-枝 の順に pre-orderで根節点から探索を行う。next_state関 数では, 再帰的に最長接尾辞に対応する節点を探索する next_node関数を用いて, 次の節点を得る. 目的の failure 関数は, make failure 関数を呼び出すことで取得できる.

次に, SeqBDDと得られた failure関数による状態遷 移を組み合わせて文字列検索を行うアルゴリズムを Algorithm 2 に示す. Algorithm 2 におけるis_terminal 関数 では，現在の状態が持つ文字列を出力すべきかを，現在 の状態が終端であるかどうか, すなわち0-枝を辿った先 に1-終端節点が接続されているかどうかで判断してい る. fail_state関数では, failure関数の出力を用いて次の 状態, すなわち次の節点とキューおよび検索対象の文字 列の位置を得る. search関数では, これらの関数を利用 


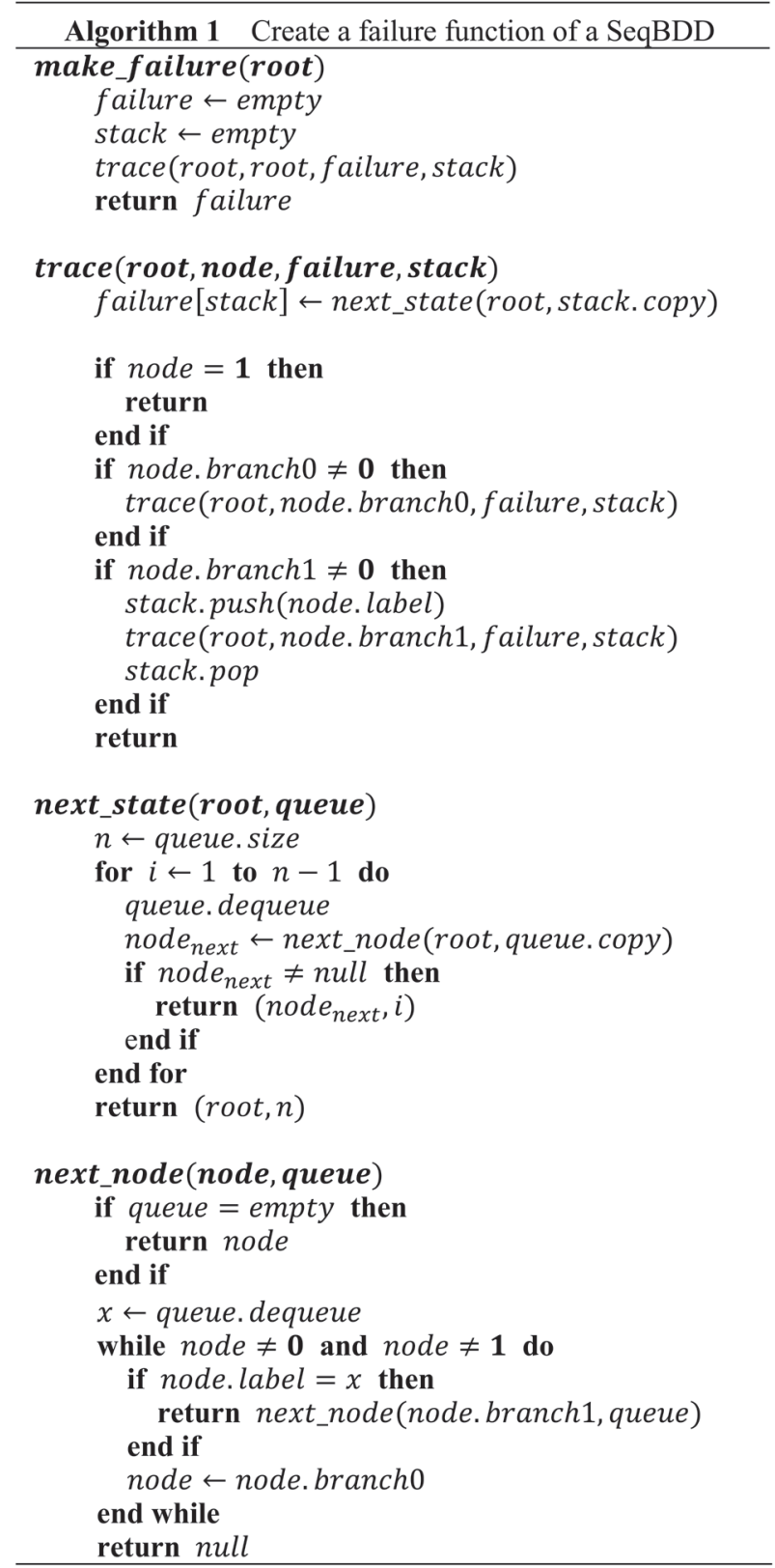

\section{し，各節点の文字と比較しながら探索する。}

Figure 10 に, Figure 9 (a) のSeqBDDに failure 関数によ る状態遷移を追加したグラフの例を示す。このグラフを 用いることで, 単純文字列マッチングよりも効率的に計 算量 $O(n+h)$ で配列モチーフ検索することができる.

\section{3 計算機実験}

\section{1 方法およびデータセット}

SeqBDDを用いたモチーフモデル (以下, 提案手法) と

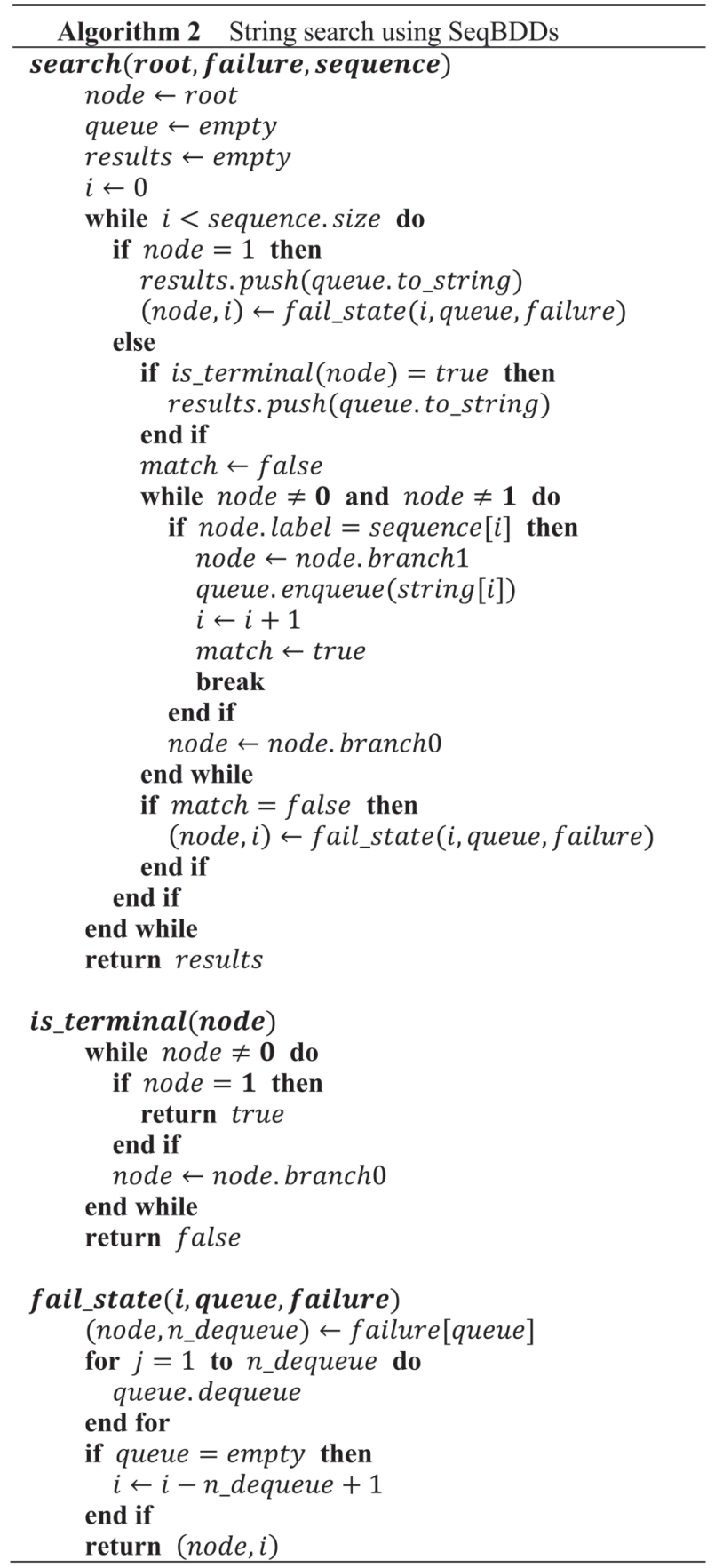

PROSITE pattern (以下, 従来法) による検索精度の比較 を，適合率，再現率，および $\mathrm{F}$ 值によって行った，検索 対象として, UniProtKB/Swiss-Prot (Release 2017_09, 以 下Swiss-Prot) [18]に登録されている全アミノ酸配列デー タ 555,594配列を用いた。 PROSITEに記載されている真 陽性配列，偽陽性配列，および偽陰性配列の情報を参 照して，精度を計算した。 モチーフモデルで表現する データとして, MMPファミリーにおいて共起する配列 モチーフである Hemopexin モチーフ, Zinc protease モチー 


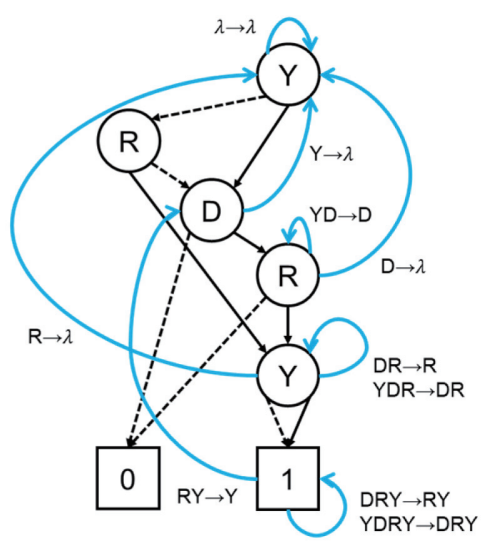

Figure 10. An example of SeqBDD by adding state transition in Figure 9 (a)

フ，およびCysteine switchモチーフを用いた. PROSITE によると, 配列モチーフを持つタンパク質は, それぞれ 98 件，1,643 件および 137 件である. 従来法には，それぞ れの配列モチーフに対応するPROSITE pattern: PS00024, PS00142，およびPS00546を用いる (Figure 1).

提案手法では, モチーフモデルを構築するために, 配 列モチーフに相当するアミノ酸配列を収集する必要があ る.しかし, PROSITEからは, 偽陰性に分類されるタ ンパク質の配列モチーフに相当するアミノ酸配列を得る ことができない. そのため, 真陽性および偽陰性に分類 されるタンパク質を対象に, 配列モチーフ抽出ツール MEME [19]を用いた配列モチーフ抽出により得られたア ミノ酸配列を用いる. MEMEによる配列モチーフ抽出 では, 配列モチーフ長をPROSITE patternの最大長に固 定し, PROSITE patternに対応する部位のうち最も E值が 低いものを使用する. 今回, 提案手法で表現する配列モ チーフを, sequence logo形式で Figure 11 に示す.

実験では，提案手法については，Denzumiらにより提 案されているアルゴリズム [12]，および2.5節に示すア ルゴリズムをC++により実装したものを, Pythonより呼 び出して使用した．従来法については, PROSITE pattern を正規表現に変換した上で, Pythonに標準で含まれてい る正規表現モジュールを用いて検索を行った.

\section{2 結果と考察}

従来法については, PROSITE patternを変換した三つの 正規表現パターンを用いて配列モチーフ検索を行う。こ

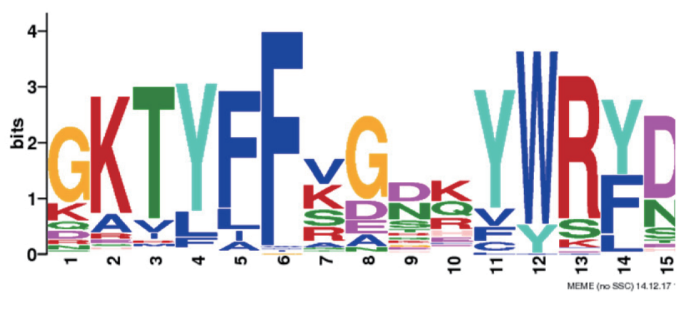

(a) Hemopexin モチーフ

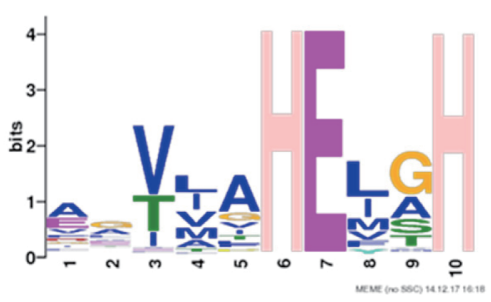

(b) Zinc protease モチーフ

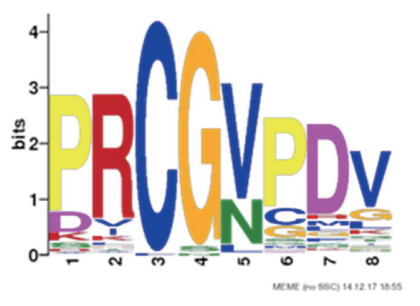

(c) Cysteine switch モチーフ

Figure 11. MMP sequence motifs extracted by MEME

のとき,一つのタンパク質に複数ヒットする場合は, 重 複を除き 1 件とカウントする. 従来法による検索結果を Table 2 に示す. Table 2 の適合率と再現率を配列モチーフ ごとに比較すると, Hemopexinモチーフについては適合 率, Zinc protease モチーフおよびCysteine switch モチーフ については再現率が低いことが確認できる.これは, 配 列モチーフに相当するアミノ酸配列を, 簡潔な文字列パ ターンで表現することの困難さを示している.

次に, 提案手法による配列モチーフ検索を行う。例え ば, Hemopexinモチーフを有するタンパク質について, 98 件のモチーフ対応部位から重複を除いた 75 件, 総残 基数 1125 の配列集合を，接点数 482 の SeqBDDにより漏 れなく表現することができる. 三つの配列モチーフを表 現するそれぞれのSeqBDDを, Table 1の和集合演算によ り一つの SeqBDD (重複を除き計 821 件, 総残基数 8473 , 
Table 2 Results of MMP sequence motif search using PROSITE pattern

\begin{tabular}{ccccccc}
\hline & $\begin{array}{c}\text { False negative } \\
\text { sequence }\end{array}$ & $\begin{array}{c}\text { False positive } \\
\text { sequence }\end{array}$ & $\begin{array}{c}\text { True positive } \\
\text { sequence }\end{array}$ & Precision & Recall & F-measure \\
\hline Hemopexin & 23 & 50 & 75 & 0.600 & 0.765 & 0.673 \\
Zinc protease & 485 & 212 & 1,168 & 0.846 & 0.707 & 0.770 \\
Cysteine switch & 65 & 2 & 72 & 0.973 & 0.526 & 0.682 \\
\hline
\end{tabular}

Table 3 Results of MMP sequence motif search using SeqBDD

\begin{tabular}{ccccccc}
\hline & $\begin{array}{c}\text { False negative } \\
\text { sequence }\end{array}$ & $\begin{array}{c}\text { False positive } \\
\text { sequence }\end{array}$ & $\begin{array}{c}\text { True positive } \\
\text { sequence }\end{array}$ & Precision & Recall & F-measure \\
\hline Hemopexin & 0 & 0 & 98 & 1.000 & 1.000 & 1.000 \\
Zinc protease & 0 & 30 & 1,643 & 0.982 & 1.000 & 0.991 \\
Cysteine switch & 0 & 19 & 137 & 0.878 & 1.000 & 0.935 \\
\hline
\end{tabular}

Table 4 List of protein sequences in MEME where another region extracted from the Cysteine switch motif

\begin{tabular}{cccc}
\hline Original sequence & Accession number & ID & Proposed sequence \\
\hline PICGNGMV & Q10743 & ADA10_RAT & MRCRLVDA \\
& O35598 & ADA10_MOUSE & GGCADHSV \\
& O14672 & GGCADHSV \\
Q10741 & ADA10_HUMAN & GGCADHSV \\
KRCGNGMV & Q9JI76 & ADA21_MOUSE & MLCSLTEK \\
DRCGNGVV & Q9UKJ8 & ADA21_HUMAN & MRCGLTEK \\
& Q9P2N4 & ATS9_HUMAN & HACDTSEH \\
& P59384 & ATS15_MOUSE & SRCGVASG \\
& Q8TE58 & ATS15_HUMAN & SRCGVASG \\
\hline
\end{tabular}

接点数 2438)に集約した後に状態遷移を追加し，アミノ 酸配列に対して検索を行った。配列モチーフ検索で得ら れたアミノ酸配列は, Hemopexin モチーフ, Zinc protease モチーフ，およびCysteine switchモチーフをそれぞれ表 現するSeqBDDの経路と比較することで分類した．提 案手法による配列モチーフ検索の結果を Table 3 に示す. Table 3の再現率が全て1であることから，SeqBDDを用 いることで, 配列モチーフに相当するアミノ酸配列を漏 れなく表現できることが確認できる. 更に, Hemopexin モチーフについては, 偽陽性配列が存在しなかったこと から, 適合率についても 1 となっている. その他の二つ の配列モチーフについては, 偽陽性配列を含んでいるこ とから, 今回の条件では配列モチーフを識別できない配 列パターンを含んでいることがわかる.

二つの手法の検索精度についての検証を, Table 2 と Table 3 の比較により行う. Cysteine switch モチーフの適 合率を除き, 提案手法の方が適合率, 再現率, および $\mathrm{F}$ 值について良いことが示される。これは, 従来法によ
る検索では偽陰性となる配列を，提案手法では検索す ることができ, 従来法の検索で偽陽性となる配列は検索 しないことにより, 検索精度の向上が達成されたと考 えられる. 一方, Cysteine switchモチーフの検索精度で は, 適合率について提案手法の精度が劣つている. これ らの配列について検証するため, Swiss-Protのエントリ 情報をもとに調査したところ, 配列モチーフではないア ミノ酸配列を含んでいることが判明した (Table 4). ここ で, Table 4のIDがADA10_RAT, ATS14_HUMANであ るタンパク質については, Swiss-ProtにCysteine switch モ チーフの情報が存在しなかった。 そのため, 真陽性配列 により最も類似性スコアの高いアミノ酸配列, すなわち 配列モチーフに相当すると期待されるアミノ酸配列を, BLASTを用いて検索した. 提案手法の含まれるアミノ 酸配列を Table 4に従い修正して, Cysteine switchモチー フについて再検索した結果を Table 5に示す. Table 5 よ り, Cysteine switchモチーフの適合率についても, 精度 が改善されたことが確認できる. しかし, 修正後の結果 
Table 5 Results of Cysteine switch motif search by SeqBDD modified according to Table 4

\begin{tabular}{ccccccc}
\hline & $\begin{array}{c}\text { False negative } \\
\text { sequence }\end{array}$ & $\begin{array}{c}\text { False positive } \\
\text { sequence }\end{array}$ & $\begin{array}{c}\text { True positive } \\
\text { sequence }\end{array}$ & Precision & Recall & F-measure \\
\hline Cysteine switch & 0 & 1 & 137 & 0.993 & 1.000 & 0.996 \\
\hline
\end{tabular}

Table 6 Results of MMP sequence motif search for MMP family proteins

\begin{tabular}{ccccccc}
\hline & $\begin{array}{c}\text { False negative } \\
\text { sequence }\end{array}$ & $\begin{array}{c}\text { False positive } \\
\text { sequence }\end{array}$ & $\begin{array}{c}\text { True positive } \\
\text { sequence }\end{array}$ & Precision & Recall & F-measure \\
\hline SeqBDD & 0 & 1 & 80 & 0.988 & 1.000 & 0.994 \\
PROSITE pattern & 27 & 0 & 53 & 1.000 & 0.663 & 0.797 \\
\hline
\end{tabular}

である Table 5 には，偽陽性に分類されているタンパク質 が1件存在する.このタンパク質 (MMP24_RAT) につい て調査するために，Swiss-Protのエントリ情報 (Q99PW6) を確認したところ，このタンパク質はCysteine switch モ チーフを持つことを確認した。 このことから，このタン パク質については，検索精度の計算に用いた分類が間 違っていたと考えられる.

最後に, Hemopexinモチーフ, Zinc proteaseモチーフ, およびCysteine switchモチーフの三つの配列モチーフを 持つタンパク質, すなわち MMP ファミリーとしての特 徵を持つタンパク質についての検索結果を Table 6に示 す.この表は，Table 2 および Table 3 から計算できる．提 案手法では, 個々の配列モチーフにおける検索精度が 良いことから期待されるように, これらの全ての配列モ チーフを持つタンパク質の検索についても，検索精度が 良いことが確認できる，その一方で，Table 6に打りる 提案手法の適合率は従来法の適合率よりも低くなってい る.この原因を調査するために，偽陽性に分類されたタ ンパク質 1 件のIDを確認したところ，このタンパク質は， 分類の間違いだと考えられるMMP24_RATであることが 判明した. すなわち, Table 6における提案手法の適合率 についても，従来法の適合率と同じく 1 となる.このこ とから, 提案手法は, 従来法と比較して, 適合率, 再現 率およびF值が全て改善されていることが示された.

\section{4 おわりに}

本研究では, 系列二分決定グラフを用いた配列モチー フ群を表現するモチーフモデルの提案を行った．提案手 法では, 配列モチーフに相当するアミノ酸配列を漏れな く表現できる.また, 提案手法による配列モチーフ検索 を行うために, Aho-Corasick法のアイディアを基にした
文字列検索アルゴリズムを導入した. 文字列検索アルゴ リズムでは，系列二分決定グラフとトライのラベルを， 根節点からトレースすることで文字列を得られるという 特徵を活用して, Aho-Corasick法と同様の状態遷移を系 列二分決定グラフ上に実現した。 このアルゴリズムと集 合演算を用いることで, 複数の配列モチーフを一つのモ デルで表現し，そのまま配列モチーフ検索を行うことが できる，計算機実験では，マトリクスメタロプロテアー ゼ・ファミリーに属するタンパク質が持つ三つの配列モ チーフを用いて, 系列二分決定グラフとPROSITE pattern の検索精度を, 適合率, 再現率, および $\mathrm{F}$ 值により比較 した. その結果, 全てのケースにおいて提案手法の方が 検索精度が良いことを示した. また, 共起するモチーフ 群を同時探索できることから，これらの組み合わせで構 成される新規モチーフの発見につながるものと考える. これは, 条件に一致する系列集合を網羅的に圧縮して表 現できる, 系列二分決定グラフの特徴によるものである.

\section{謝辞}

本研究の一部は, 栢森情報科学振興財団の研究助成 （K30研XXII第536号）を受けて実施したものであるこ とを明記して謝意を表す。

\section{参考文献}

[1] D. W. Mount, Bioinformatics: Sequence and Genome Analysis, Cold Spring Harbor Laboratory (2004)

[2] H. Toh, M. Ono, K. Saigo, T. Miyata, Nature, 315, 691 (1985). DOI:10.1038/315691a0

[3] B. Kobe, A. V. Kajava, Curr. Opin. Struct. Biol., 11, 725 (2001). DOI:10.1016/S0959-440X(01)00266-4 , PMID:11751054 
[4] S. Lanouette, J. A. Davey, F. Elisma, Z. Ning, D. Figeys, R. A. Chica, J. F. Couture, Structure, 23, 206 (2015). DOI:10.1016/j.str.2014.11.004 , PMID:25533488

[5] T. Akutsu, Mathematics and Algorithms of Bioinformatics, Kyoritsu Shuppan (2007), in Japanese.

[6] C. J. A. Sigrist, E. de Castro, L. Cerutti, B. A. Cuche, N. Hulo, A. Bridge, L. Bougueleret, I. Xenarios, Nucleic Acids Res., 41, D1, D344 (2012). DOI:10.1093/nar/ gks1067, PMID:23161676

[7] R. D. Finn, P. Coggill, R. Y. Eberhardt, S. R. Eddy, J. Mistry, A. L. Mitchell, S. C. Potter, M. Punta, M. Qureshi, A. Sangrador-Vegas, G. A. Salazar, J. Tate, A. Bateman, Nucleic Acids Res., 44, D1, D279 (2016). DOI:10.1093/nar/gkv1344, PMID:26673716

[8] S. Azuma, H. Kato, Development of the structural feature analysis system based on the motif combination pattern of proteins, Chem-Bio Informatics Society Annual Meeting 2015, P3-7 (2015)

[9] H. E. Van Wart, H. Birkedal-Hansen, Proc. Natl. Acad. Sci. USA, 87, 5578 (1990). DOI:10.1073/ pnas.87.14.5578, PMID:2164689

[10] M. Itoh, J. C. Nacher, K. Kuma, S. Goto, M. Kanehisa, Genome Biol., 8, R121 (2007). DOI:10.1186/gb-2007-86-r121, PMID:17588271
[11] Z. Wang, X. C. Zhang, M. H. Le, D. Xu, G. Stacey, J. Cheng, PLoS One, 6, e17906 (2011). DOI:10.1371/ journal.pone.0017906, PMID:21455299

[12] E. Loekito, J. Bailey, J. Pei, Knowl. Inf. Syst., 24, 235 (2010). DOI:10.1007/s10115-009-0252-9

[13] S. Denzumi, R. Yoshinaka, H. Arimura, S. Minato, Discrete Appl. Math., 212, 61 (2016). DOI:10.1016/j. dam.2014.11.022

[14] ERATO Minato Discrete Structure Manipulation System Project, Super-High-Speed Graph Enumeration Algorithm, Morikita Shuppan (2015), in Japanese.

[15] M. Yoneda, N. Osato, S. Hirose, S. Okawa, Fundamentals of Automaton and Linguistic Theory, Kindai Kagakusha (2003), in Japanese.

[16] R. D. L. Briandais, File searching using variable length keys, Proc. Western J. Computer Conf., 295-298 (1959)

[17] A. V. Aho, M. J. Corasick, Commun. ACM, 18, 333 (1975). DOI:10.1145/360825.360855

[18] The UniProt Consortium, Nucleic Acids Res., 45, D1, D158 (2017). DOI:10.1093/nar/gkw1099, PMID:27899622

[19] L. J. Bailey, T. J. Cluett, A. Reyes, T. A. Prolla, J. Poulton, C. Leeuwenburgh, I. J. Holt, W. W. Li, W. S. Noble, Nucleic Acids Res., 37, 2327 (2009). DOI:10.1093/nar/gkp091, PMID:19458158

\section{The Multiple Representation of Protein Sequence Motifs Using Sequence Binary Decision Diagrams}

\footnotetext{
Kohei YAMATO $^{\text {a }}$, Hiroaki KATO ${ }^{\text {b* }}$, Tetsuo KATSURAGI ${ }^{\text {a }}$, Yoshimasa TAKAHASHI ${ }^{\text {a }}$

a Department of Computer Science and Engineering, Toyohashi University of Technology, 1-1 Hibarigaoka, Tempaku-cho, Toyohashi, Aichi 441-8580, Japan

${ }^{\mathrm{b}}$ Department of Distribution and Information Engineering, National Institute of Technology, Hiroshima College, 4272-1 Higashino, Osakikamijima-cho, Toyota-gun, Hiroshima 725-0231, Japan

In this paper, we describe a multiple representation method of protein sequence motifs using sequence binary decision diagrams (SeqBDDs) and their application for motif search. A SeqBDD is a compressed representation of a set of sequences such as multiple strings. In this study, we developed two algorithms for SeqBDDs. The first is for constructing a SeqBDD which expresses amino acid sequences of the corresponding motifs, and the second is for building an automaton equivalent to a deterministic finite automaton for a SeqBDD by adding state transition to it. For the evaluation of their performances, we used our method to search for three highly conserved domains in the matrix metalloproteinase (MMP) family against all 555,594 amino acid sequences obtained from UniProtKB/Swiss-Prot (Release 2017_09) and compared results with the similar searches using PROSITE patterns. The methods showed better results on precision, recall and F-measure than those of using PROSITE patterns.
}

Keywords: sequence binary decision diagram, Aho-Corasick algorithm, multiple representation, sequence motif, motif search 